\title{
Radovan Vukadinović (1938-2019)
}

\author{
DEJAN JOVIĆ
}

Fakultet političkih znanosti, Sveučilište u Zagrebu

U Zagrebu je 22. svibnja 2019. preminuo prof. dr. sc. Radovan Vukadinović. Nekoliko dana kasnije ispraćen je i pokopan na zagrebačkom groblju Mirogoj pored svoje supruge, nedavno preminule naše kolegice Lidije Čehulić-Vukadinović. Tragedija koja je zadesila obitelj Vukadinović smrću dvoje istaknutih profesora međunarodnih odnosa, koji su zadnjih petnaestak godina bili i životni partneri, snažno je odjeknula u srcima mnogih koji su ih poznavali, čitali, slušali na predavanjima i cijenili.

Profesor Radovan Vukadinović bio je doajen studiranja međunarodnih odnosa u Hrvatskoj te jedan od malobrojnih istaknutijih osnivača i stvaralaca te poddiscipline na granici između politologije i drugih srodnih akademskih disciplina u okvirima nekadašnje Jugoslavije. Oblikovao je i sigurnom rukom predvodio način na koji su se međunarodni odnosi razvijali na Fakultetu političkih nauka/znanosti u Zagrebu, a potom i na nekoliko drugih - mnogo kasnije osnovanih - institucija, kao što su Visoka škola za međunarodne odnose Dag Hammarskjöld u Zagrebu i Univerzitet Donja Gorica u Podgorici, a također i na Diplomatskoj akademiji Ministarstva vanjskih (sada i europskih) poslova, na koju je također imao značajnog utjecaja.

S izuzetkom šest mjeseci od 1. srpnja 1962. do 31. prosinca iste godine (kad je radio u Institutu za društveno upravljanje u Zagrebu, koji ga je i stipendirao kao studenta prava), profesor Vukadinović je cijeli svoj radni vijek - punih 45 godina radio na Fakultetu političkih znanosti, na kojem se zaposlio 1. siječnja 1963. Otišao je u mirovinu 30. rujna 2008. s napunjenih 70 godina života (rođen je 18. ožujka 1938. u Bitoli, u sadašnjoj Sjevernoj Makedoniji, a tada Kraljevini Jugoslaviji - u kojoj mu je otac, Spasoje Vukadinović, službovao kao prosvjetni radnik). Otac je rano umro, pa se majka, Zdravka rođ. Kravar, također prosvjetna radnica rodom iz 
Šibenika, seli u Zadar, u kojem Radovan polazi u osnovnu i srednju školu. U tim godinama u Zadru im oslonac pruža majčin brat Miroslav Kravar, jedan od osnivača i prvi dekan Filozofskog fakulteta u Zadru, istaknuti slavist. Radovan Vukadinović će u ranim danima, uz ujaka, učiti poljski, pa će s Poljskom ostati vezan i profesionalno i privatno, budući da je njegova prva supruga, Mirosława, bila Poljakinja. Iz tih ranih dana datira i njegovo cjeloživotno prijateljstvo s Budimirom Lončarom, tada već profesionalnim diplomatom koji je dobro poznavao obitelj njegove majke. Lončar ga je dodatno upućivao u teme iz međunarodne politike, koje su ih povezivale kasnije u karijerama koje su izgradili. Poljska "veza" pomogla je Vukadinoviću i da uspostavi bliske odnose sa Zbigniewom Brzezinskim, savjetnikom za nacionalnu sigurnost američkog predsjednika Jimmya Cartera i istaknutim analitičarem iz područja međunarodnih odnosa, a profesionalni i prijateljski odnosi s Lončarom bili su i jedan od razloga što je Vukadinović bio involviran u pripremu Devetog summita nesvrstanih u Beogradu 1989.

Diplomirao je na Pravnom fakultetu u doba kad je njegov dekan bio Rikard Lang. Međutim, u njegovoj daljnjoj karijeri mnogo će važnija biti dvojica drugih profesora tog fakulteta, Juraj Andrassy (rođen 1896, od 1937. redovni profesor, umro 1977) i Vladimir Ibler (rođen 1913, umro 2015). Oni su bili i u komisiji za doktorat koji je Vukadinović obranio 12. prosinca 1967. na FPN-u pod naslovom "Političko-pravni aspekti suradnje socijalističkih država članica SEV-a" (430 stranica; treći član komisije bio je Ante Marušić, tada docent na FPN-u) te u čak četiri komisije za kasnije izbore u akademska zvanja: docenta (izabran je 6. ožujka 1968, treći član komisije bio je također Ante Marušić), izvanrednog profesora (izabran 18. svibnja 1972, treći član komisije bio je Dragovan Šepić) i redovnog profesora (prvi je put izabran u to zvanje 11. travnja 1976, treći član komisije - uz Andrassya i Iblera - bio je Dušan Bilandžić), kao i u prvom potvrđivanju zvanja redovnog profesora (izvještaj od 9. prosinca 1977, treći je član tada ponovno bio Dragovan Šepić).

Moglo bi se stoga reći da su profesori Andrassy i Ibler imali presudan utjecaj na Vukadinovićev rani akademski razvoj. On je bio pravnik po osnovnom (preddiplomskom) obrazovanju, ali se odmah specijalizirao za međunarodne odnose, razdvajajući se od discipline međunarodnog prava - manje-više po metodološkim postavkama koje je Ibler postavio u svojoj studiji u hrestomatskom djelu Međunarodni odnosi (Naprijed, Zagreb, 1971). Vukadinović je od 1962. do 1964, kao mladi asistent na predmetu "Suvremeno društvo i međunarodni odnosi" na FPN-u, pohađao i potom završio magistarske studije iz međunarodnog prava i međunarodnih odnosa (voditelj je bio profesor Juraj Andrassy) na Pravnom fakultetu, te je stekao zvanje magistra prava. Međutim, doktorat mu je već bio u "čistom" politološkom području, iako su mu u komisiji za obranu bila dva istaknuta profesora prava. Ali, to je bila uobičajena stvar za prve godine od nastanka Fakulteta političkih nauka, 
kad se on oslanjao na "bratsku pomoć" drugih disciplina, najčešće prava. Vukadinović je i kasnije ostao povezan s Pravnim fakultetom, na kojem je dugo predavao na postdiplomskim studijima. No, ubrzo se - kao glavna osoba koja je određena da nastavnički, istraživački, organizacijski i kadrovski razvija područje međunarodne politike - profilirao kao politolog. Iako je primljen kao asistent, već je 1965. (kad je magistrirao) postao "predavač", $\mathrm{i}$ to na predmetu "Osnovi diplomacije i moderna diplomatska povijest", a već od 1968. ima svoj predmet - "Međunarodni politički odnosi" - na kojem predaje kao docent, a kasnije na njemu ostaje do mirovine (i ostavlja ga Fakultetu kao obavezan predmet za studente politologije, na trećoj godini studija, sve do danas). To znači da zapravo nikad nikome nije bio asistent, nego je za sebe gradio nišu kojom će neupitno vladati sve do odlaska u mirovinu a djelomično do konačnog razlaza s fakultetom na kojem je radio, povod čemu je bio izbor drugog nastavnika, a ne Vukadinovića, za profesora emeritusa 2012. Poslije toga profesor Vukadinović, tada umirovljen, prekinuo je sve veze s fakultetom - osim u slučaju vrlo malog broja (mislim samo dvoje) doktorskih studenata čije je teze mentorirao do kraja. Bio je to "potpuni" kraj odnosa, kakvih je u povijesti tog fakulteta, međutim, i ranije znalo biti - iz raznih razloga.

No, vratimo se na akademski profil profesora Vukadinovića, a posebno na njegov doprinos formiranju i oblikovanju discipline međunarodnih odnosa, prije svega kroz knjige i članke koje je objavio. Taj se profil donekle može rekonstruirati uvidom u izvještaje za izbore u zvanja, koje smo imali prilike proučiti povodom pisanja ovog članka. Nećemo, naravno, navoditi čak ni naslove svih objavljenih knjiga, nego ćemo umjesto toga - u kratkim crtama - ustanoviti doprinose koje je profesor Vukadinović dao svom području.

Njegovi prvi članci datiraju još u 1965. godinu kad je u Našim temama (znaju li uopće danas studenti, pa i mlađi kolege, što su bile Naše teme, kojih nema u internetskom prostoru i koje dijele sudbinu prilične nezainteresiranosti za sve što se objavljivalo prije 1990. iako predstavljaju prvorazredan izvor za neko buduće pisanje povijesti društvenih znanosti i humanistike u Hrvatskoj?) objavio članak o novom privrednom sistemu u Čehoslovačkoj, a u Političkoj misli iste godine članak o GATT-u te godinu kasnije o Organizaciji afričkog jedinstva (u broju 1-2/1966) i o internordijskim odnosima (4/1966). U Poljskoj objavljuje članak o nastanku politologije u Zagrebu, u Pregledu članak o političkim kretanjima u Africi, a krajem 1966. i jedan o NATO-u. Od ovih radova, povjerenstvo za izbor u zvanje docenta naročito je istaklo vrijednost rada o internordijskim odnosima, te je kandidata pohvalilo za temeljitost, samostalnost i kritičnost. Nordijskim temama Vukadinović se počeo baviti tijekom svog studijskog boravka u Oslu (najprije nakratko 1966, a potom na duže, temeljem stipendije Nordijskog vijeća u 1968). Iste godine (od 1. travnja do 31. srpnja) odlazi na usavršavanje u Dansku. Nordijske teme kasnije za- 
mjenjuju teme o neutralnosti, dok komparativno-političke aspekte prepušta Štefici Deren-Antoljak, danas, nažalost, malo poznatoj profesorici FPN-a. Međutim, ostaje ipak činjenica da je upravo Vukadinović prvi u nas posvećivao pažnju Nordijskom vijeću, da je razvijao odnose sa Sveučilištem u Oslu i s kopenhaškim COPRI-jem, koji su u 1970-ima i, u slučaju COPRI-ja, u 1980-ima bili doista na samom vrhu (barem europske) politologije međunarodnih i sigurnosnih studija. Sudjelovao je u projektu Norveškog instituta za međunarodne odnose (1970-1971), a i kasnije je (2000) studijski bio povezan s COPRI-jem.

Po stjecanju doktorata znanosti Vukadinović se bavi pitanjima vanjske politike SAD-a prema socijalističkim zemljama, procesom i koncepcijama europskog ujedinjavanja te idejom jedinstvene Europe. Pišući o tim temama već 1967. i 1968. (u doba Lyndona Johnsona i Leonida Brežnjeva), on otvara nova područja istraživanja u našoj politologiji. Po mnogočemu je zapravo prvak europskih studija u nas, barem kad se radi o politologiji. Iz današnje je perspektive čitanje njegovih članaka od prije 50 godina i dalje vrlo zanimljivo i korisno, budući da se o istim tim temama - na tek donekle različit način - piše i danas. Pritom neki koji o njima pišu uopće ne uzimaju u obzir da iza sebe imaju pedesetogodišnju "arhivu" članaka svojih prethodnika, od kojih je Vukadinović sasvim sigurno najznačajniji. Članovi povjerenstva pohvaljuju ga posebno zbog "načina mišljenja i izlaganja koje izbjegava moralnopolitičke osude i pohvale", ističući da ga odlikuje "nepolemički ton i nastojanje da se shvate stavovi, a ne da se autor politički opredjeljuje". Komisija ga je pohvalila što je, pišući o Americi i Europi, "izložio i suprotna gledišta" - drugim riječima, što nije bio propagandist državne politike. Međutim, ni ta državna politika tada nije bila ni na strani Istoka ni na strani Zapada, tako da je neutralnost i ekvidistanca prema oba "pola" tada bipolarnog poretka bila poželjna i nije ga smjestila među kritičare poretka. Vukadinović će se kasnije razvijati kao netko tko je, doista, gotovo podjednako zainteresiran za Istok (SSSR, Poljsku, Kinu, Vijetnam, Čehoslovačku i dr.) kao i za Zapad (SAD, Francusku, Europu). Bit će i po temama i po pristupima sveobuhvatan: ponekad možda suviše deskriptivan, ali uvijek vrlo dobro informiran i temeljit. Koristio je i čitao literaturu s pet-šest jezika (uključujući poljski, slovački, kao i bugarski - kako je naveo u radnom listu pri prvom zapošljavanju), a putovanja i kontakti koje ostvaruje čine ga u svijetu jednim od naših najpoznatijih politologa. U doba daleko prije interneta, kad je dostupnost izvora bila još uvijek relativno ograničena, ti kontakti davali su mu veliku prednost u odnosu na mnoge druge kolege, a on je to vrlo dobro koristio. Osobno mogu posvjedočiti da je Radovan Vukadinović dugo, čak i u devedesetim godinama, bio Mr International Relations s naših prostora - najpoznatije ime u ovom području iz Hrvatske, a ranije vjerojatno i Jugoslavije. On je toga, dakako, bio svjestan, pa je jednom prilikom kasnije mlađim kolegama rekao: "Kolege, u Jugoslaviji međunarodni odnosi - to sam bio ja. 
A možete onda zamisliti u Hrvatskoj.” Manje-više bio je u pravu, barem gledano izvana. Uz njega su, međutim, postojali i drugi, kao što su Radovan Pavić, Branko Caratan, Štefica Deren-Antoljak, Vlatko Mileta i mlađi - no oni nisu dosegli takvu međunarodnu prepoznatljivost kao Vukadinović.

Od samog početka karijere Vukadinović je vrlo plodan autor, koji piše ne samo znanstvene radove nego i feljtone u Vjesniku (o međunarodnim odnosima, 1967), eseje za radijske emisije (Treći program Radio Zagreba, o Vijetnamu, o krizi koncepcija u okvirima NATO-a, o europskoj politici Charlesa de Gaullea, o problemima afričkih zemalja, o europskoj politici SAD-a te o europskoj sigurnosti), a održava i javna predavanja o Vijetnamskom ratu, nesvrstavanju, suradnji socijalističkih zemalja i vanjskoj politici SFRJ.

Za izvanrednog profesora izabran je 1972. godine, u doba kad je dekan fakulteta bio Ante Pažanin, a predsjednik Savjeta Zvonimir Baletić. U izvještaju o izboru stoji da je od 1968. do tada objavio dvije knjige (ujedno i njegove prve dvije: Odnosi među europskim socijalističkim državama: SEV i EU, 1970, 328 stranica, nastalu iz doktorata, te kraću knjižicu Vanjska politika NR Kine, iste godine, 86 stranica). Za prvu knjigu nominiran je za Nagradu grada Zagreba, tada prestižno društveno priznanje. Te godine ju nije dobio, ali jest za knjigu Međunarodni politički odnosi - 1975. godine. Uz dvije navedene knjige objavio je u te četiri godine i šest studija, 22 članka i 10 radijskih predavanja. Napisao je 11 recenzija i prikaza knjiga. Posebno se bavio pitanjima suradnje istočne i sjeverne Europe (nastavljajući s interesom za nordijske zemlje te njihov odnos sa SSSR-om), pitanjima europske suradnje i sigurnosti te pitanjima vanjske politike SAD-a, SSSR-a i Kine. Knjiga o Kini, kao i članci koji su objavljeni na tu temu, bili su iznimno aktualni s obzirom na poboljšanje američko-kineskih odnosa (Nixonovu posjetu Kini 1972. godine), pokušaje da se rat u Vijetnamu privede kraju, kao i ideološke teme povezane s kineskim putem u socijalizam. Vukadinović piše i o kineskoj armiji i o kulturnoj revoluciji i o Nixonovoj doktrini. Uz to, međutim, razvija fantastičan spektar tema u svojim objavljenim djelima. U tom razdoblju njegove su teme i: Lenjinova koncepcija u stvaranju sovjetske vanjske politike, politika Kanade, vanjska politika Jugoslavije, pitanje ograničavanja suvereniteta, male zemlje i politika nesvrstavanja, Varšavski ugovor i vojnopolitičko integriranje istočne Europe, socijaldemokracija u nordijskim zemljama, američko-kineski odnosi, vojno-industrijski kompleks u stvaranju vanjske politike SAD-a, mehanizmi vanjskopolitičkog odlučivanja u SAD-u, SAD i Zapadna Europa, finska neutralnost, Afrika i suvremeni međunarodni odnosi te antiraketni sistemi.

Takav raspon tema dijelom proizlazi iz potrebe da u nastavi "obuhvati" mnoge suvremene teme tadašnjeg svijeta, a teme su se "same nametale". Zahvaljujući i profesoru Vukadinoviću, Politička misao je u tim godinama relativno brzo nakon 
što bi se pojavila neka tema iz međunarodne politike imala već članak o njoj - ili čak i tematski broj, kao što je bio slučaj s čehoslovačkom krizom (iz ljeta 1968) već u broju 2/1969. Da bismo ilustrirali kako je to bilo moguće, navodimo samo da su u tom broju članke o različitim aspektima čehoslovačke krize objavili Radovan Pavić (jedan samostalno, drugi s Andrijom Bognarom), Jovan Mirić (o teorijama ograničenog suvereniteta), Andrija Bognar i sam Radovan Vukadinović. Tko je bio (ili jest) urednik časopisa dobro zna da je tako promptna reakcija - da godinu dana nakon nekog događaja nastane poseban broj - indikator akademske živosti i relevantnosti. Iako objavljuje primarno u Političkoj misli (kojoj je od 1974. do 1983. bio glavni i odgovorni urednik, s najdužim mandatom na tome mjestu dosad), Vukadinović surađuje i s Kulturnim radnikom, Pitanjima, Pregledom, Teorijom in praksom i Međunarodnim problemima.

Za redovnog je profesora (prvi put) izabran 26. travnja 1976, a nakon potvrde tadašnjeg Savjeta fakulteta (predsjedavao mu je u tom trenutku Ante Marušić) inauguriran je 3. rujna te godine. Stjecajem okolnosti kasnije će još triput biti "potvrđivan", odnosno biran za redovnog profesora: prvi put već krajem 1977, potom 1986, a zatim 1998, vjerojatno zbog promjena propisa koji su (uz za hrvatska sveučilišta uobičajenu praksu da se tek drugi izbor smatra "trajnim" i konačnim) tražili dodatne izbore i reizbore.

U razdoblju na koje se odnosi izvještaj o izboru za redovnog profesora Vukadinović je bio i prodekan (1970-1972). Kasnije (od 1980. do 1982) bit će i dekan Fakulteta političkih nauka. Od 1976. pa sve do odlaska u mirovinu - dakle, više od 30 godina - bio je voditelj poslijediplomskog studija (kako se tada zvao magistarski, za stjecanje magisterija znanosti) Međunarodni odnosi, na kojem je, pod njegovim ravnanjem, $u$ desetak ciklusa stvoren priličan (za to vrijeme) broj magistara znanosti. Mnogi od njih radili su u diplomaciji i u sigurnosnim organizacijama, u vojsci tadašnje Jugoslavije i kasnije Hrvatske, ali i drugih zemalja nastalih raspadom Jugoslavije, tako da je Vukadinović stvorio širok krug sadašnjih alumnija. Rečeno suvremenim rječnikom, on je bio najuspješnija spona između svijeta znanja i svijeta rada na tom fakultetu - uz bok možda samo s kolegama koji su razvijali komunikologiju / novinarstvo te (do 1990) studije obrane i zaštite. Bio je zainteresiran za ono granično polje koje se i danas nalazi između "specijalističkih" odnosno "stručnih" i pravih "akademskih" studija. Neki njegovi kolege i suvremenici znali su reći da je Vukadinović bio vrlo susretljiv kad bi se radilo o magisterijima, ali ne i doktoratima: što, čak i iz današnje perspektive, zapravo i ima opravdanja jer se doktoratom znanosti stječe i mogućnost kasnijeg ulaska u akademsko polje, a po tom je pitanju on bio prilično konzervativan. Nije sebi stvorio očiglednog nasljednika, iako se uvijek oslanjao na suradnike i asistente (asistentice, u njegovu slučaju: Božicu Blagović, Kseniju Jurišić, kasnije Lidiju Čehulić-Vukadinović), tako da je njegovim 
odlaskom u mirovinu nastalo pitanje "nasljeđivanja". Ali, teško je bilo naslijediti nekoga s takvim profilom.

No, vratimo se u 1976. kad je izabran za redovnog profesora - bez raspisivanja javnog natječaja, što je tada bilo moguće ako sama institucija zaključi da ima kandidata koji ispunjava uvjete. Taj izvještaj naglašava da je od 1972. napisao tri knjige: Sila i interesi: vanjska politika SAD (398 stranica), Međunarodni politički odnosi (1974, inicijalno 298 stranica, ali kasnije proširivana u novim izdanjima) te - zajedno s profesorom Dušanom Bilandžićem - Osnovni problemi međunarodnih odnosa nakon Drugog svjetskog rata (1973; Vukadinovićev dio je na stranicama 149-283). Knjiga Međunarodni politički odnosi njegova je najpoznatija publikacija, koja je od tada pa sve do danas udžbenik na istonazvanom predmetu na FPZG-u. Prevedena je na više jezika, pa je i danas u upotrebi u Poljskoj, na Kosovu, u Crnoj Gori i drugdje. Nju je kasnije Vukadinović nadopunjavao i mijenjao - posebno nakon 1990, kad je u novim izdanjima svojih knjiga objavljenih u doba socijalizma ili sasvim reducirao ili isključio dijelove o marksizmu i marksističkim teorijama, smatrajući ih vjerojatno irelevantnima u novim okolnostima - ali od nje nikad nije odustao, niti ju je kasnije zamijenio nekim novim, tako sveobuhvatnim, radom.

U svojim - stvaralački gledano - najboljim godinama Vukadinović objavljuje sedam članaka, 19 eseja i 19 prikaza knjiga, baveći se intenzivno temama tog vremena: konferencijom o europskoj sigurnosti i suradnji (1977-1978. provest će u Beogradu, kao savjetnik jugoslavenske delegacije na Konferenciji o europskoj sigurnosti i suradnji), europskim odnosima, američko-sovjetskim odnosima, Finskom, Španjolskom, sovjetskom vanjskom politikom i nesvrstavanjem, političkim kretanjima na Mediteranu, odnosima SAD-a i Zapadne Europe, pitanjem denuklearizacije europskog sjevera, ulogom multinacionalnih kompanija u formiranju vanjskih politika te naftom i bliskoistočnom politikom SAD-a. Ima i jedan članak o kvantitativnim metodama u studiranju međunarodnih političkih odnosa, iako nikad nije bio poznat po takvim pristupima. U ranim sedamdesetima serijom radijskih emisija na Trećem programu Radio Zagreba široj javnosti predstavlja eseje koji će kasnije naći mjesta u njegovim knjigama Teorije vanjske politike i Suvremene teorije međunarodnih odnosa. Pa ipak, iako nije zanemarivao ni literaturu o teorijama, one nisu bile njegov forte, što je i sam priznavao. Iznosim iz vlastitog sjećanja da je, kad smo pokrenuli ediciju o teorijama međunarodnih odnosa, rekao da "nam to nedostaje" i da se na fakultetu tom temom "nisu bavili", osim onoliko koliko je bilo apsolutno nužno radi studenata. Vukadinović je bio na drugom polu akademskog spektra u odnosu na snažnu grupu profesora političke teorije i filozofije na fakultetu na kojem je radio, što je stvorilo - po mom sudu neproduktivnu i nepotrebnu - podjelu između "teoretičara" i "praktičara", koju je trebalo premostiti nakon njegova odlaska u mirovinu. 
U drugom izvještaju za redovnog profesora, napisanom 9. prosinca 1977, komisija potvrđuje da je kandidat dostojan tog zvanja, što dokazuje time da je od prošlog izbora (dakle u samo godinu i pol) objavio još tri monografije (Europska sigurnost i suradnja, 1977, 340 stranica; Bezatomske zone i europska sigurnost $i$ suradnja, 1977, 201 stranica; Američko-sovjetski odnosi od 1917. do 1976., 1977, 175 stranica). Uz to, objavio je i 19 novih članaka, četiri prikaza knjiga i šest eseja za radio.

Treći izvještaj, iz 1986, ujedno je i prvi u kojem više nema ni Juraja Andrassya ni Vladimira Iblera, nego komisiju predvodi Božidar Bakotić, a članovi su Vlatko Mileta i Branko Caratan. Trojac Vukadinović - Mileta - Caratan tada čini jezgro studiranja međunarodne politike na FPN-u. Radovan Vukadinović bavi se sigurnosnim pitanjima tadašnjeg svijeta (iako na fakultetu postoji poseban studij općenarodne obrane i društvene samozaštite), euro-atlantskim odnosima (koji će kasnije, nakon 1990. postati jedan od njegovih fokusa), američko-sovjetskim i strateškim pitanjima. U tim godinama više se ne bavi intenzivno nesvrstanošću, koju je i tako "prepuštao" drugim jugoslavenskim kolegama, ponajprije Ranku Petkoviću, s kojim je dugo i dobro surađivao. Vukadinović u tim godinama objavljuje i knjigu $\mathrm{Nu}$ klearne strategije supersila (1985), kao i Mediteran između rata i mira (1986). Za knjigu Teorije međunarodnih odnosa 1978. dobio je republičku Nagradu "Božidar Adžija". (On, "praktičar", a ne "teoretičar"!) U razdoblju koje ovaj izvještaj opisuje navodi se da je Vukadinović bio predsjednik Politološkog društva SR Hrvatske (danas: Hrvatskog politološkog društva). Bio je i predsjednik izdavačkog savjeta nakladničke kuće August Cesarec. Od 1979. do 1983. vodi znanstveni projekt "Međunarodni odnosi SFRJ i europske integracije", a sudjeluje na projektima u Norveškom institutu za međunarodne odnose, Londonu, Zürichu i Tokiju. Od 1985. neprekidno je gostujući profesor na Florida State University.

Raspad Jugoslavije Vukadinovića zatječe kao 52-godišnjaka. Iako nije bio jedan od onih koji su se snažnije politički angažirali u godinama socijalizma, Vukadinović nije bio ni protivnik Jugoslavije ni protivnik socijalizma. Bio je član Saveza komunista od 1956. godine, iako se nikad nije isticao u tom pogledu, niti je bio član partijskog rukovodstva (kao što su bili profesori Dušan Bilandžić, Tomislav Jantol, Zdravko Tomac i Branko Caratan). Nije bio ni kritičan ni suviše apologetičan prema jugoslavenskoj vanjskoj politici. Kao stručnjak za međunarodne odnose striktno se čuvao involviranja u unutarnjopolitička pitanja koja su već krajem osamdesetih razdirala Jugoslaviju. Česta putovanja na konferencije i studijske boravke (zbog kojih je nastavu u velikoj mjeri prepustio svojoj tadašnjoj asistentici Kseniji Jurišić) dodatno su ga "spašavala" od unutarnje politike.

Početkom 1990-ih fakultet se našao u neizvjesnoj situaciji jer se nije znalo kakve su namjere novih vlasti prema postojećoj politologiji. Trebalo se dokazivati na 
novim temeljima kako bi se prevladala blokada koju je nova vlast (bivšeg vanjskog profesora FPN-a Franje Tuđmana i HDZ-a) primjenjivala prema - sada preimenovanom - Fakultetu političkih znanosti. Bio je, osim toga, i rat: donekle je bilo i logično da znanost i visoko obrazovanje nisu bili među prioritetima. Vukadinović je vidio što se događa i aktivno se uključio u pomaganje novoj hrvatskoj državi kako bi ona stvorila diplomate, profesionalne vojnike i svoje snage sigurnosti, te time $i$ razvila glavne pravce strategije vanjske politike i obrane. On predaje na Vojno-diplomatskoj školi, kao i na Diplomatskoj akademiji Ministarstva vanjskih poslova, novim institucijama koje u Jugoslaviji nisu postojale (u Zagrebu). Mnogi službenici, od najniže do najviše rangiranih, slušaju u tim godinama njegova predavanja i grade karijere objavljujući u publikacijama kojima je Vukadinović urednik te stječući zvanja pod njegovim mentorstvom. Među najpoznatijima koje je mentorirao na magistarskom ili doktorskom studiju su Kolinda Grabar-Kitarović (magisterij 2000), Gordan Grlić-Radman (magisterij 2002), Davor Božinović (magisterij 2003. i doktorat 2007), Drago Lovrić (magisterij 2001. i doktorat 2012) te Jozo Radoš (magisterij 2011). Povrh toga, profesor Vukadinović mentorirao je magisterije i doktorate nekih današnjih nastavnika Fakulteta, kao što su: Lidija Kos-Stanišić (magisterij 1999), Đana Luša (magisterij 2007. i doktorat 2011) te Božo Skoko (magisterij 2003). Sve to vrijeme on nije bio "slijep" za probleme s kojima se suočila nova hrvatska država ne samo na vanjskopolitičkom nego i na unutarnjopolitičkom i društvenom planu. Sjećam se njegova dobronamjerna savjeta iz 1994. godine, kad mi je rekao: "Kolega, Vaša zemlja od Vas očekuje da odete". Bio je to odgovor na moju dilemu - otići na studij u inozemstvo ili ostati na fakultetu u tim godinama. Pa ipak, njegovi su savjeti bili diskretni, nikad javni. U javnosti je ostao odan stavu da unutarnja politika nije njegovo područje, pa da ga stoga ne bi smjela omesti u radu kojem je posvetio cijeli život. Kad sam se, nakon 15 godina, odlučio ipak vratiti, bio je predsjednik povjerenstva u postupku izbora nastavnika koji će dobiti "njegov" posao - na kojem sam izabran za izvanrednog profesora. Tom se povratku, rekao bih iskreno, radovao, iako me nije propustio upozoriti na to u što se vraćam, kao i reći da se on - u mojoj situaciji - ne bi vratio.

Njegove zasluge za kreiranje hrvatske vanjskopolitičke strukture kao i za "aktivan rad na promociji hrvatske državne politike u svijetu" istakli su i u svom izvještaju Branko Caratan, Vlatko Mileta i Bernard Vukas kad su ga 1998. predlagali za ponovni izbor za redovnog profesora. Napisali su tada da je ukupno objavio 118 članaka, od kojih su 92 bila znanstveni radovi. No, u skladu s novim vremenom, smatrali su potrebnim istaći da se Vukadinović "u danima borbe za samostalnu Hrvatsku... perom uključio u obranu hrvatske suverenosti i isticanje prava hrvatskog naroda na vlastitu državu”. Da bi to ilustrirali, trojica članova povjerenstva citiraju Pierrea Hassnera, koji je napisao da mu je Vukadinović već 1971. (za boravka 
na Sveučilištu Columbia) "najavio nezavisnost Hrvatske". Komisija ističe da se "u svakom od radova (on) snažno založio za međunarodno priznanje hrvatske države i potrebu ispravnog sagledavanja novih realnosti”. Vjerojatno je i zbog toga, kao i "za osobite zasluge stečene promicanjem međunarodnog položaja i ugleda Republike Hrvatske i njezina odnosa s drugim državama", Radovan Vukadinović iz ruku predsjednika Republike Stjepana Mesića 10. lipnja 2009. dobio odlikovanje: Red kneza Branimira s ogrlicom. Predsjednik Ivo Josipović imenovat će ga članom Savjeta za vanjsku politiku i međunarodne odnose, u kojem je djelovao aktivno i konstruktivno. Potom će njegova studentica Kolinda Grabar-Kitarović postati predsjednica Republike. Grabar-Kitarović bila je bliska Radovanu Vukadinoviću i njegovoj supruzi Lidiji Čehulić-Vukadinović, s kojima je surađivala u okviru Atlantskog vijeća, koje je Radovan Vukadinović osnovao 2001. i bio mu predsjednik sve do smrti. Vijeće je organiziralo - uz podršku NATO-a - ljetnu školu na Šipanu, koja je osnovana 2002, te je sve do 2016. publicirala i godišnjak. Ta je ljetna škola, kao i zbornik, bila u potpunosti Vukadinovićevo “dijete”. U školi je sudjelovalo oko dvije tisuće sudionika iz brojnih zemalja. Fokus je bio na odnosima NATO-a i zemalja jugoistočne Europe. To je jedna od najvećih akademskih i stručno-političkih mreža koje su stvorene u toj regiji, zaslugom profesora Vukadinovića.

U zadnjem desetljeću svog djelovanja na Fakultetu političkih znanosti Vukadinović je stvarao i aktivno sudjelovao u radu stručnih institucija koje su bile polupovezane s fakultetom te su ubrzo razvile svoju izdavačku, stručnu, a dijelom i akademsku djelatnost. Izdvajaju se Centar za međunarodne studije i Hrvatska udruga za međunarodne studije (osnovana 2. travnja 1999, predsjednik joj je bio Radovan Vukadinović, a potpredsjednici Vlatko Mileta i Marinko Krešić). Vukadinović je bio i spiritus movens pri osnivanju privatne Visoke škole međunarodnih odnosa i diplomacije Dag Hammarskjöld, koja je osnovana 2009. godine, a ove godine priključila se Sveučilištu Libertas. Ta je visoka škola u međuvremenu razvila značajnu nastavnu aktivnost, koja je u velikoj mjeri bila rezultat rada Radovana Vukadinovića i njegovih najbližih suradnika. Škola mu je omogućila da i nakon umirovljenja (2008) ostane nastavnički aktivan i u Zagrebu. Nekoliko godina od osnivanja Vukadinović je bio i dekan Fakulteta humanističkih studija na Univerzitetu Donja Gorica (u Podgorici). S Crnom Gorom je ostao povezan i na temelju osnivanja Škole evroatlantizma u Baru, te je aktivno sudjelovao u brojnim akademskim aktivnostima u toj zemlji, s kojom ga veže porijeklo i brojna prijateljstva. U prvom desetljeću 21. stoljeća objavljuje i nove knjige: Međunarodni odnosi od hladnog rata do globalnog poretka (2001), Politika europskih integracija (s Lidijom Čehulić, 2005), NATO u međunarodnim odnosima (također s Lidijom Čehulić-Vukadinović, 2006), NATO: euroatlantska integracija (s Lidijom Čehulić-Vukadinović i Davorom Božinovićem, 2007) te Amerika i Rusija (2008). 
Uz to, Vukadinović je bio i komentator za vanjskopolitičke teme u brojnim medijima u Hrvatskoj. Nekoliko dana prije smrti komentirao je Brexit za Hrvatsku televiziju, a gostovao je i u emisijama o američkoj vanjskoj politici.

Profesor Vukadinović ostavio je iza sebe golemo djelo koje će u godinama koje slijede sigurno biti i dodatno znanstveno evaluirano. Značajan prvi korak u tom pravcu učinila je Đana Luša člankom o razvoju discipline međunarodnih odnosa u časopisu Politička misao od 1964. do 1987. (objavljenom u ovom časopisu, broj 1/2014). Njegove brojne knjige i članci bit će predmet daljnjih istraživanja, ali već se sada može sa sigurnošću reći da je neumorno radio i mnogo toga iza sebe ostavio - i u pisanom obliku i kroz nastavničku, uredničku i lidersku aktivnost - pa povijest studiranja međunarodnih odnosa u Hrvatskoj mora poći od temeljite analize njegova značajnog doprinosa. Institucije koje je oblikovao, radovi koje je napisao (od kojih su neki sabrani u posebnu ediciju njegovih Izabranih djela, objavljeni u izdanju Političke kulture iz Zagreba 2009. godine u tri sveska) te mreža suradnika, studenata i poštovatelja koju je stvorio ostat će i nakon njegove smrti svjedočanstvo njegova doprinosa hrvatskoj politologiji. 